\title{
Resenha sobre o livro O Ocaso da Clínica: A Medicina de Dados
}

\author{
Review of the book O Ocaso da Clínica: A Medicina de Dados
}

Reseña del libro O Ocaso da Clínica: A Medicina de Dados

O OCASO DA CLÍNICA: A MEDICINA DE DADOS. Vianna Sobrinho L. São Paulo: Zagodoni Editora; 2021. 170 p. ISBN: 978-65-86711-22-6.

doi: 10.1590/0102-311X00135521

O livro O Ocaso da Clínica: A Medicina de Dados traz um conjunto de reflexões sobre a saga da medicina nos últimos 50 anos, da emergência da medicina social, traduzida na Declaração de Alma-Ata e no Sistema Único de Saúde (SUS), até a consolidação da medicina de mercado e, mais recentemente, da medicina dos dados, baseada na inteligência artificial. Nesse percurso, o livro une temas que costumam ser discutidos separadamente pelos sanitaristas - Reforma Sanitária, biomedicina, financeirização, medicina baseada em evidências e valor, telemedicina. Embora essa miscelânea possa suscitar críticas relacionadas à falta de aprofundamento conceitual dos temas, considero essa tentativa de síntese um ponto forte do livro.

O autor, Luiz Vianna Sobrinho, é médico de formação e prática profissional e constrói seu trabalho como uma trilogia de tinturas caleidoscópicas. Às vezes, esse estilo gera parênteses excessivos, mas seu principal mérito é acelerar associações que contribuem para inovar a forma como pensamos questões antigas e novíssimas na pauta da saúde pública.

A obra marca a evolução de um pensamento que já se debruça, há algum tempo, sobre as relações entre medicina e mercado. Em seu trabalho anterior Medicina Financeira: A Ética Estilhaçada 1 , a preocupação principal é a discussão da metamorfose da prática médica vinculada à financeirização: "pacientes são negociados em carteiras, como ações", "patologias são precificadas como commodities", como coloca o autor em entrevista sobre essa obra 2.

Em seu trabalho atual, é como se Vianna Sobrinho renovasse essa reflexão partindo de uma nova pergunta - como o mercado vem ganhando essa disputa com a Reforma Sanitária e para onde isso vai nos conduzir? Inspirado em um diálogo com a filosofia, em seu doutorado orientado por Fernando Telles Salgado, parece tentar avançar ainda mais na exploração do ferramental e das estratégias que a financeirização adotou na sua busca por lucratividade. Nesse percurso, ganhamos reflexões que trazem conceitos da escolástica, bebem das águas da epistemologia de Lakatos e deságuam em clara busca de inspiração em Foucault para pensar o "renascimento da clínica", sinalizando um marco teórico eclético.

As principais hipóteses de Vianna Sobrinho em seu livro são claramente colocadas na sua abertura. Podem soar polêmicas para quem milita na saúde pública, mas são um estrondoso alerta. Vianna Sobrinho considera que houve um equívoco epistemológico na proposta da Reforma Sanitária ao quase satanizar a biomedicina, ao tentar afastá-la de seu núcleo teórico e de seu foco político. O que se viu, na prática, foi um fortalecimento e crescente protagonismo econômi- 
co, político e social da biomedicina e uma cisão incontornável entre ela e a saúde coletiva.

No primeiro capítulo, o autor discute exatamente esse esforço da Reforma Sanitária em transformar seu "núcleo duro" epistemológico e substituí-lo por uma visão social mais ampla, priorizando os determinantes sociais no processo saúde doença. Mas pondera que se trata de uma migração talvez perigosamente frágil: "admitindo estar a biomedicina vinculada aos interesses econômicos das forças de mercado (...) desejava-se fugir da ótica instrumentalista de consumo de serviços e tecnologias. Isso fez do projeto da Reforma Sanitária um modelo científico fraco. A biomedicina, por seu turno, como um núcleo teórico robusto em franco crescimento, pela geração de fatos novos, foi capturada definitivamente como característica do mercado" (p. 23).

Dito de outra forma, o projeto do SUS, fruto do pensamento da Reforma Sanitária, fragilizouse ao renunciar à biomedicina. E, nesse processo, cindiu médicos e não médicos. E médicos entre si.

A segunda parte do livro - A Medicina Gestionária: A Chegada da Cultura do Capital Financeiro - retoma a discussão da financeirização travada em sua obra anterior. Se ali o centro da discussão era o questionamento dos fundamentos éticos do trabalho médico no contexto capitalista financeirizado, nesse novo trabalho, o autor parte mais uma vez do papel do médico para questionar os motivos da transformação da prática médica contemporânea. Indaga-se sobre sua relação com uma mudança cultural decorrente da acelerada incorporação tecnológica (como uma instrumentalização da semiologia). Mas, ao fim, defende que a mudança, de fato, foi a introdução da linguagem da gestão - a Medicina Gestionária - e, fundamentalmente, a emergência da Medicina Baseada em Evidência. Há fartas evidências da incorporação desses conteúdos nos currículos das faculdades de medicina atuais. Conteúdos de gestão passavam longe da formação médica clássica, totalmente centrada na clínica, e consolidam a visão de que a prática da medicina é um negócio a ser gerido.

O Ocaso da Clínica: A Medicina de Dados é o ponto de chegada dessas reflexões. Aqui o autor vincula a medicina baseada em evidências a algoritmos, protocolos e bioinformática. Enxerga um desdobramento da "captura" de um núcleo duro consistente da biomedicina e seu ferramen- tal mais quantitativo pela medicina de mercado. Agora, o conhecimento médico passa a ser fortemente baseado em dados e cada vez mais flerta com a inteligência artificial.

A partir disso, Vianna Sobrinho propõe que os dados sejam o novo núcleo duro da medicina. Essa é uma visão que pode ser contestada - na prática, dados e evidência sempre basearam a construção da medicina científica, como ferramentas. O que não se imaginava é que a ferramenta (o dado) passasse a dominar o trabalhador e, como em Eu, Robô, de Isaac Asimov 3, se candidatasse à essência do processo de cuidado. Mais que uma crítica à adoção da tecnologia, Vianna Sobrinho nos traz aqui uma crítica à lógica de geração da tecnologia, que acaba dominando seus usos.

Determinantes sociais - o candidato a núcleo duro de um possível programa de pesquisa de Reforma Sanitária - configuram um núcleo perigosamente frágil porque destacam vulnerabilidades e, com elas, a insuficiência de nossos recursos materiais. A crise da COVID-19 destacou as carências de recursos humanos treinados em cuidados de alta tecnologia como um dos seus desafios. Bem entendido, destaca-se carência de recursos altamente treinados nos princípios da biomedicina.

Nesse ponto, podemos fazer pontes entre o trabalho de Vianna Sobrinho e reflexões vinculadas à economia da saúde, como as de Baumol 4. O setor saúde é intensivo em mão de obra e apresenta baixa produtividade do trabalho. O humano é, por assim dizer, inimigo da produtividade. Uma solução de mercado para aumentar sua eficiência (lida aqui como ser lucrativo ainda que os recursos sejam escassos) é a redução do aporte humano. Com isso, valida-se a implantação definitiva do self-service tecnológico travestido de autonomia do paciente e de boas práticas profissionais pautadas por protocolos. Cria-se um modelo de negócios, um Admirável Mundo Novo 5 , baseado em wearable devices que registram continuamente sinais vitais, sequenciamentos genômicos disponíveis já na vida intrauterina, robôs que assumem parte dos cuidados e inteligência artificial para realizar projeções a partir de dados continuamente captados.

A clínica, base histórica da profissão médica, baseada na observação humana que estabelece 
laços de confiança em relações médico-paciente, será assim inexoravelmente transformada. O médico do futuro, no melhor cenário, restará transmutado em um gestor de equipe de bioinformáticos e cientistas da computação. "O que está em jogo é justamente a perda do controle individual do profissional sobre o saber" (p. 61).

Ao fim da leitura, fechando o anel entre o primeiro e o último capítulo, não consigo me furtar a suspeitar que a mais recente ameaça à Reforma Sanitária passará pelo confisco de seu coração na atenção primária (medicina "menos complexa”) por algoritmos e apps de autodiagnóstico e monitoramento. Isso vai demandar a rediscussão do que entendemos por atenção primária. E um aprofundamento da discussão ética que inaugura as reflexões do autor.

Em suma, este é um livro que vale a pena ser lido e tem o dom de evocar mais perguntas do que respostas.

Maria Angelica Borges dos Santos 1

${ }^{1}$ Escola Nacional de Saúde Pública Sergio Arouca, Fundação Oswaldo Cruz, Rio de Janeiro, Brasil.

angelicabsantos@uol.com.br

\section{Informação adicional}

ORCID: Maria Angelica Borges dos Santos (00000002-7547-3537).

1. Vianna Sobrinho L. Medicina financeira: a ética estilhaçada. Rio de Janeiro: Garamond; 2013.

2. Mathias M, Torres R. O que se quer é que se consuma o quanto mais. Outras Saúde 2018; 19 fev. https://outraspalavras.net/outrasaude/me dicina-financeira/.

3. Azimov I. Eu, Robô. São Paulo: Editora Aleph; 2014.

4. Baumol WJ. The cost disease. Why computers get cheaper and health care doesn't. New Haven: Yale University Press; 2012.

5. Huxley A. Admirável mundo novo. Rio de Janeiro: Biblioteca Azul; 2014.

Recebido em 01/Jun/2021

Aprovado em 15/Jun/2021 